\title{
PRONOUN PRODUCTION ORDER IN A GENDER-NEUTRAL LANGUAGE: A SINGLE CASE STUDY OF A TYPICALLY DEVELOPING INDONESIAN CHILD
}

\author{
Bernard A. J. Jap
}

\begin{abstract}
Research in children with normal language development has shown that there is a certain order in the production and learning of pronominal forms. To one's knowledge, there has yet to be a study on the pronoun development of Indonesian speaking children whose native language do not distinguish between the nominative-accusative form (e.g. in English, I/me - Indonesian, saya/saya) and at the same time being gender neutral (e.g. in English, he/she - Indonesian, dia/dia). The present study follows the personal pronoun development of a (Jakarta) Indonesian-speaking child from 24 months to 46 months of age.
\end{abstract}

Keywords

pronoun development, normal child language, early language development, Indonesian language

\begin{abstract}
Abstrak
Penelitian terhadap anak dengan perkembangan bahasa normal telah menunjukkan bahwa ada urutan tertentu dalam pembelajaran dan produksi bentuk-bentuk pronomina. Sepengetahuan penulis, belum ada studi mengenai perkembangan pronomina personal anak berbahasa Indonesia. Bahasa Indonesia tidak membedakan pronomina nominatif dan akusatif (misalnya, dalam bahasa Inggris, I/me Bahasa Indonesia, saya/saya) dan pada saat yang bersamaan tidak membedakan jenis kelamin dalam pronomina (misalnya, dalam bahasa Inggris, he/she - Bahasa Indonesia, dia/dia). Studi ini mengikuti perkembangan pronomina personal seorang anak yang berbahasa (Jakarta) Indonesia sejak umur 24 bulan hingga 46 bulan.
\end{abstract}

Kata Kunci

perkembangan pronomina, bahasa anak normal, perkembangan bahasa awal, Bahasa Indonesia

\section{INTRODUCTION}

Speech roles are of vital importance for a young child learning to communicate. To interact with another, certain interpersonal knowledge is needed: for instance, to refer to oneself with I or to another with you or he/she. Investigating how or in what order does the child acquire personal pronouns may reveal insights into how this particular awareness could contribute to his/her language and speech role knowledge.

Numerous researches have been conducted on the order of production of 
pronouns on both typically developing children and individuals with Specific Language Impairment (SLI). Some studies have established a certain order of production in typically developing children. Bol and Kasparian (2009), for example, mentioned that demonstrative pronouns precede personal pronouns. Subjects of the study also depict that all Mean Length of Utterance $\left(\mathrm{MLU}^{1}\right)$-divided groups of Dutch children (i.e. below 3, 3 to 4, and above 4) are able to produce the first, second, and third person singular pronouns. The feminine third person singular and the plural second person pronoun are not produced in all groups while the plural first person and third person are acquired in certain MLU stages. The pronoun het (it) is produced only at the group with the highest MLU. Slightly different findings were put forward by Chiat (1986) where, in general, while children start with the first person singular and inanimate third person singular that precedes the second person, these personal pronouns do not appear in a rigid order. Additionally, these 'predictable' pronouns are subject to restricted usage in specific context and position, and "confusions between different personal pronouns rarely occur," (Chiat, 1986: 349). Though perhaps pronoun reversal errors are associated with ASD or other impairments, a more recent study by Evans and Demuth (2012) has showed the fact that even typically developing precocious children may display pronoun reversals (in this case, using second person pronouns to refer to herself) as a result of "semantic confusion". The authors compared one child with Asperger's syndrome and a typically developing child in an attempt to reveal underlying mechanisms of pronoun reversal. Caselli, Casadio, and Bates (1999) in a two-language study found that pronominal production order is highly similar for both Italian and English despite some incomparable aspects (Italian has several reflexive and clitic pronouns). They proposed that the first person is acquired first, but the second person is acquired second while the third person pronoun is last. This is not in accordance to the previous studies mentioned, but again one has to note that the order of pronominal production is not well established.

These articles (among many others) are attempts at establishing a hypothesis to explain pronoun acquisition in children. The difference in findings within many articles shows contending hypotheses to explain the phenomenon. The semantic complexity hypothesis, confirmed by the order of Italian and English acquisition by Casseli, Casadio, and Bates (1999), suggests that pronominal development in children is influenced by the semantic complexity of individual pronouns. In this context, the order of acquisition should be the first person, followed by the second person, and finally the third person (Chiat, 1982). She suggests that not only is this hypothesis irrelevant to atypical speech, but there is little evidence that pronoun acquisition is dictated by conceptual or linguistic features used to exemplify adult pronominal usage. Consequently, she proposed the

\footnotetext{
1 Mean Length of Utterance is used to measure linguistic development and productivity in children. Often it is linked with morphosyntactic and lexical development throughout the (earlier) ages.
} 
plurifunctional pronoun hypothesis to explain pronoun reversals, but this will not be explained in detail as it is not of interest to the paper's topic.

The second hypothesis is the person-role hypothesis proposed by Charney (1980). The speech-role hypothesis argues that the order of production of personal pronouns (especially $1 p$ vs $2 p$ ) depends on the role that the child usually takes. If the child is the speaker, $1 p$ is more likely to precede $2 p$, and if the child is the addressee, $2 p$ is more likely to precede $1 \mathrm{p}$. When the child is the speaker, $2 \mathrm{p}$ production is accompanied by non-deictic 3p.

The name hypothesis begs to differ by drawing from the fact that shifting pronominal reference is a difficult feat for early learners. Therefore, children will use pronouns as 'proper' names and make consistent reversal errors (Clark, 1978 in Evans and Demuth, 2012).

Contradictory to the name hypothesis, the speech-role hypothesis insists that most children could acquire and accurately produce pronouns because speech roles and pronouns have an inseparable relationship (Clark, 1978 in Girouard, Ricard, and Décaire, 1997). Though evidence for supporting the speech-role hypothesis are numerous ${ }^{2}$ as mentioned by Girouard, Ricard, and Décaire (1997), they have also provided counter evidence for this hypothesis on their longitudinal study of 12 French and 12 English speakers.

These hypotheses will be the theoretical basis of this paper's discussion on answering a research question: what is the personal pronoun production order in a typically developing Indonesian child?

\section{PERSONAL PRONOUNS IN INDONESIAN}

It is worth to note that there are several types of pronouns in Indonesian. Aside from personal pronouns, there are also demonstrative, indefinite, number, reflexive, locative, and interrogative pronouns (Sneddon, 1996). Of interest to this discussion is the usage of personal pronouns in Indonesian, which encompasses only several pronominal words. The Indonesian language does not distinguish between the nominative or accusative case marking nor gender in both first and third person pronouns. Table 1 below displays the pronouns discussed.

\begin{tabular}{|l|l|l|l|l|l|}
\hline I(intimate) & I(polite) & You & You & He/She/It & We(Inclusive) \\
\hline Aku & Saya & Kamu & Kau & Dia & Kita \\
\hline
\end{tabular}

Table 1. Pronouns in subject

2 Speech-role hypothesis' evidence for comprehension: Sharpless, 1974. Evidence for production: Shipley \& Shipley, 1969; Huxley, 1970; Sharpless, 1974; Clark, 1978; Chiat, 1981. (Girouard, Ricard, and Décaire, 1997: 312) 
While there are other pronouns that are tested such as $l u$, lo (two colloquial forms of 'you'), anda (polite form of 'you'), engkau (a form of 'you' rarely used in oral speech, usually shortened to kau), kami (the exclusive form of 'we' which means 'us without you' where 'you' is the addressee), mereka (them), and kalian (plural form of the second person pronoun), they are excluded in the data because there is no substantial production recorded in the subject's speech sample which may have these pronouns marked as 'acquired'.

There is also another ubiquitous pronoun gua/gue that originates from the Jakarta/ Betawi dialect which is used to refer to oneself in an intimate/non-polite manner. This pronoun also did not show up in the dataset (which is as expected since young children are discouraged to use it to refer to themselves in the presence of their parents). Koenraad (1975) also stated that personal pronouns or titles that show family relation, status, or function as well as given names are frequently used for formal second person singular and plural. However, such a case is not prominent in MIC's dataset due to higher complexity (perhaps acquisition is later) and is therefore ignored. The interesting preference of accusative for nominative case pronoun as mentioned by Leonard (2000) is unfortunately not of relevance since Indonesian pronouns do not (at least overtly) mark for the nominative-accusative distinction.

\section{METHOD}

The data of this study comes from CHILDES' East Asian corpora. Speech sample for the chosen subject is gathered from March 2000 to January 2002. According to the CHILDES manual for East Asian corpora, data collection and processing follows a regular routine where research assistants visit the home of a child to record target child's natural language in a natural setting.

There are 8 Indonesian children recorded in the corpora, and several considerations are made to choose the most representative sample depicting exemplary pronoun production development of a Standard Indonesian speaker. The first criterion is that there are no other languages spoken at home. Keeping in mind that most Indonesians do not acquire Indonesian as their first language, this is an essential filter to record first language pronoun acquisition. There are two candidates that match this criteria: PRI and MIC (RIS may actually qualify since traditional Betawi which is inserted in "Other languages spoken at home" column is a dialect/variation of Indonesian rather than another language, but for the sake of consistency RIS will be excluded).

MIC is chosen at last because the dataset shows that MIC's early recordings show almost no usage of personal pronouns at all, so the moment of pronoun acquisition throughout the 22 months of data will be recorded. PRI shows a rather prolific production of the third person pronoun dia in her earliest data (11 times in a month's recording, age 2 years and 7 months). Additionally, PRI and MIC has a rather similar Mean Length of 
Utterance (MLU) development age-wise. PRI's first month of recording at age 2 years and 7 months show an MLU of 2.3 is relatively equivalent compared to MIC's MLU of 2.4 at the same age. This suggests that both candidates have similar linguistic development and capacity (as to refute possible claims of an atypical linguistic capability of MIC). MIC is also within an age range of early 'paradigmatic reference', which Bates (1990) mentions as the first moments that children distinguish between different personal pronouns. Children below 20 months of age would either be in a contrastive/non-contrastive reference and are only starting to see, for example, the emergence of a child's own name and other proper nouns, though a few begin to contrast "I" and "you" at 20 months.

MIC was 2 years old at the time of the first recording. There are a total of 89 speech samples analysed, and each sample was recorded periodically ranging from two to five times per month. The CLAN program was used to analyse the majority of the data, and the data is compiled and calculated in Microsoft Excel. Calculation of MLU value is in accordance with Brown's (1973) set of rules as shown in the CLAN Manual. The first page of the transcription should be skipped while maintaining a 100-utterance dataset, thus, instead of getting the first 100 utterances, this study uses " $+z 25 u-125 u$ " in the MLU command to skip the first 25 utterances which is about a page (MacWhinney, 2000: 114).

\section{RESULTS}

The two charts below depict MLU and pronoun production development throughout the recording. Pronoun production uses the total number of pronouns per recording throughout the study and divides it by the total number of utterances per recording. This is done due to the randomness of pronominal production alongside with having only one subject- if one were to use 100 utterances only, it is certain that chance will play its part and data will not be depicted as is- or even worse without any comparisons of other subjects. As expected, both MLU and number of pronoun produced show a linear upward trend. Although MLU has a rather mild fit to the regression line $\left(\mathrm{R}^{2}=0.49\right)$, it still shows MLU development through the age as a typically developing child (perhaps a plateau is imminent in the higher ends of the MLU value). Pronoun regression line interestingly becomes a better determiner $\left(R^{2}=0.6\right)$ of the trend.

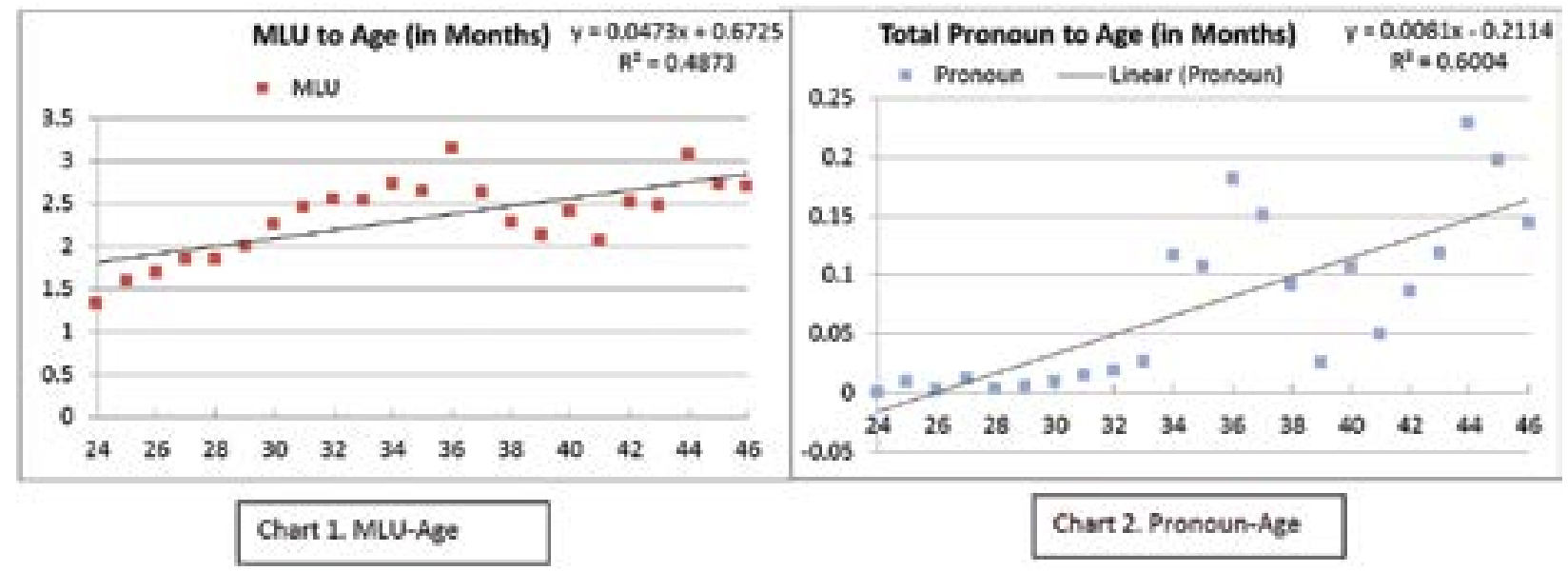


The results are displayed in Table 2. A green highlight indicates acquisition, which is defined as the production of a certain pronoun that at least occurs four times in 100 analysable spontaneous utterances (Bloom, 1970 in Bol and Kasparian, 2009). A blue one means that acquisition is fulfilled when two pronouns with the same referent (e.g. $a k u$ and saya) is combined in number within that 100 utterances range. Determining personal subject pronoun acquisition in Indonesian speech samples is quite tricky since the same word can be used as a subject, object, as well as a possessive pronoun. Below is an example of usage of dia in the object position.

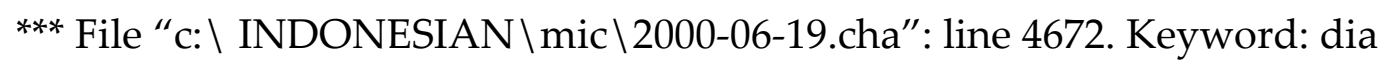
${ }^{*} \mathrm{CHI}$ : waduh, ini dia (.) betul[?] . (trans.: oh no, this is him/her/it (.) right[?].)

Table 2. below counts all forms of pronouns regardless of their syntactic role. However, when frequency is recorded above 4 in any particular file, each occurrence of the pronoun is investigated in its context by using the kwal command in CLAN. Underlined numbers indicate either non-subject usage (which deems it irrelevant towards the acquisition counter) or usage that are not in range of the 4-in-100 utterance requirement. The elicited acquisition order is $1^{\text {st }}$ person singular, followed by $2^{\text {nd }}$ person singular, and finally $3^{\text {rd }}$ person singular accompanied by $1^{\text {st }}$ person plural.

\begin{tabular}{|c|c|c|c|c|c|c|c|c|c|}
\hline $\begin{array}{c}\text { Age } \\
\text { (Month) }\end{array}$ & $\begin{array}{c}\text { I } \\
\text { Aku }\end{array}$ & $\begin{array}{c}\text { I } \\
\text { Saya }\end{array}$ & $\begin{array}{c}\text { You } \\
\text { Kamu }\end{array}$ & $\begin{array}{c}\text { You } \\
\text { Kau }\end{array}$ & $\begin{array}{c}\text { Overall } \\
\text { for I }\end{array}$ & $\begin{array}{c}\text { Overall } \\
\text { for You }\end{array}$ & $\begin{array}{c}\text { He/She/It } \\
\text { Dia }\end{array}$ & $\begin{array}{c}\text { We } \\
\text { Kita }\end{array}$ & $\begin{array}{c}\text { MLU } \\
\text { MIC }\end{array}$ \\
\hline 24 & 0 & 0 & 0 & 0 & 0 & 0 & 0 & 0 & 1.33 \\
\hline 25 & 0 & 2 & 1 & 0 & 2 & 1 & $\underline{8}$ & $\underline{4}$ & 1.58 \\
\hline 26 & 0 & 0 & 1 & 0 & 0 & 1 & 1 & 1 & 1.69 \\
\hline 27 & 0 & 0 & 2 & 0 & 0 & 2 & $\underline{12}$ & 2 & 1.84 \\
\hline 28 & 2 & $\underline{4}$ & 0 & 1 & $\underline{6}$ & 1 & 1 & 0 & 1.85 \\
\hline 29 & 2 & 1 & 1 & 0 & 3 & 1 & 0 & 0 & 2.00 \\
\hline 30 & 0 & 3 & $\underline{4}$ & 1 & 3 & $\underline{5}$ & 2 & 3 & 2.26 \\
\hline 31 & 3 & $\underline{13}$ & $\underline{6}$ & 1 & $\mathbf{1 6}$ & $\underline{7}$ & 2 & 0 & 2.45 \\
\hline 32 & 0 & 1 & 14 & 0 & 1 & $\mathbf{1 4}$ & 0 & 2 & 2.56 \\
\hline 33 & $\underline{7}$ & 3 & 5 & 0 & 10 & 5 & 0 & 1 & 2.53 \\
\hline 34 & 66 & 1 & 43 & 1 & 67 & 44 & 39 & 7 & 2.72 \\
\hline 35 & 52 & 5 & 11 & 0 & 57 & 11 & 39 & 22 & 2.64 \\
\hline 36 & 74 & 6 & 52 & $\underline{5}$ & 80 & 57 & 46 & 26 & 3.14 \\
\hline 37 & 82 & 10 & 33 & 0 & 92 & 33 & 42 & 37 & 2.62 \\
\hline 38 & 21 & 6 & 30 & 1 & 27 & 31 & 15 & 15 & 2.27 \\
\hline 39 & 10 & 2 & 2 & 0 & 12 & 2 & 8 & 7 & 2.12 \\
\hline 40 & 87 & 3 & 12 & 0 & 90 & 12 & 16 & 4 & 2.39 \\
\hline 41 & 32 & 1 & 5 & 0 & 33 & 5 & 25 & 12 & 2.07 \\
\hline 42 & 77 & 0 & 8 & 0 & 77 & 8 & 12 & 11 & 2.51 \\
\hline
\end{tabular}




\begin{tabular}{|c|c|c|c|c|c|c|c|c|c|}
\hline $\begin{array}{c}\text { Age } \\
\text { (Month) }\end{array}$ & $\begin{array}{c}\mathrm{I} \\
A k u\end{array}$ & $\begin{array}{c}\mathrm{I} \\
\text { Saya }\end{array}$ & $\begin{array}{c}\text { You } \\
\text { Kamu }\end{array}$ & $\begin{array}{c}\text { You } \\
\text { Kau }\end{array}$ & $\begin{array}{c}\text { Overall } \\
\text { for I }\end{array}$ & $\begin{array}{c}\text { Overall } \\
\text { for You }\end{array}$ & $\begin{array}{c}\text { He/She/It } \\
\text { Dia }\end{array}$ & $\begin{array}{c}\text { We } \\
\text { Kita }\end{array}$ & $\begin{array}{c}\text { MLU } \\
\text { MIC }\end{array}$ \\
\hline 43 & 63 & 0 & 12 & 1 & 63 & 13 & 15 & 20 & 2.47 \\
\hline 44 & 133 & 1 & 46 & 0 & 134 & 46 & 13 & 45 & 3.07 \\
\hline 45 & 30 & 1 & 37 & 0 & 31 & 37 & 23 & 34 & 2.72 \\
\hline 46 & 70 & 8 & 13 & 0 & 78 & 13 & 6 & 5 & 2.69 \\
\hline
\end{tabular}

Table 2. MIC's Pronominal Acquisition and Frequency

\section{DISCUSSION}

The order of acquisition of MIC is largely in concordance to other proposed production orders with the $1^{\text {st }}$ person acquired first. An enigmatic question would be whether dia is really the final pronoun to be acquired (together with kita). Dia encompasses he, him, his, she, her, and it, and has a wide range of referents. Though this may provide a simplistic referent to the child as he could refer to many different things with one word, such simplicity may be derived from the viewpoint of adult pronominal usage. Contrary to such a proposition, dia might actually prove to be difficult for the child to acquire as the shift of referents is sometimes inconsistent (e.g. his toy is dia, and so is his mother when he is talking to the experimenter). This complexity also agrees with the semantic complexity hypothesis where the third person in Indonesian may even be more complicated since it heavily involves pragmatics, just as the first and second person pronouns are (e.g. saying saya to one's parents is inappropriate, as is using $a k u$ to a stranger/ someone newly acquainted). With the mix of people that visits and interacts with MIC, there should not be a problem with preferential usage of certain personal pronouns. However, MIC learns to eventually use $a k u$ to the experimenter as they have seen each other for many months. This is evidence of his pragmatic development.

The results show that it is compliant to the person-role hypothesis to a certain extent. While it is true that MIC is almost always prompted to speak and is the center of attention for most if not all of the meetings (hence, the acquisition of $1^{\text {st }}$ person prior to $2^{\text {nd }}$ person pronouns), the fact that the third person is acquired two months later after the second person is in contrast to the person-role hypothesis' (Charney, 1980) prediction of acquiring $3^{\text {rd }}$ person together with the $2^{\text {nd }}$ when the child constantly becomes the speaker and not the addressee.

The presented data is in favour of speech-role hypothesis as opposed to name hypothesis. Although pronominal referents may be difficult, pronoun reversals are not found, and MIC certainly does not "use pronouns like names," or "not attending to the effect that speech roles have on shifting reference," (Evans \& Demuth, 2012 :168). The acquisition comes naturally with the given speech-roles that MIC has to use.

By far the most convincing explanation for why the third person came after 
second and first is the fact that, as the model of Oshima-Takane, Takane, and Shultz (1999) shows, a complete understanding of the speech roles assigned to different pronouns require both the child to be the addressee and the non-addressed. MIC lacks latter situations as he is always prompted to talk. This is also in line with the idea of Ricard, Girouard, and Décaire (1999) that only a non-addressee can be referred to using $3 p$ : $1 p$ and $2 p$ do not refer to $3 p$. This needs MIC to experience such situation. Future research on Indonesian pronoun acquisition order needs more subjects to confirm results and increase generalization power. The weakness of this single-case study is apparent because pronoun acquisition is sensitive to individual differences.

\section{REFERENCES}

Bates, Elizabeth. "Language about me and you: Pronominal reference and the emerging concept of self." The self in transition: Infancy to childhood. Chicago: University of Chicago Press. 1990: 165-182.

Bloom, Lois Masket. "Language development: Form and function in emerging grammars." Cambridge, MA: The MIT Press. 1968.

Bol, Gerard W., and Kristina Kasparian. "The production of pronouns in Dutch children with developmental language disorders: A comparison between children with SLI, hearing impairment, and Down's syndrome." Clinical Linguistics E Phonetics 23.9, 2009: 631-646.

Caselli, Cristina, Paola Casadio, and Elizabeth Bates. "A comparison of the transition from first words to grammar in English and Italian." Journal of child language 26.1, 1999: 69-111.

Charney, Rosalind. "Speech roles and the development of personal pronouns." Journal of child language 7.3, 1980: 509-528.

Chiat, Shulamuth. "If I were you and you were me: The analysis of pronouns in a pronoun-reversing child." Journal of Child Language 9.02, 1982: 359-379.

Chiat, Shulamuth. "Personal pronouns." Language acquisition. Cambridge: Cambridge University Press.1986: 339-355.

Evans, Karen E., and Katherine Demuth. "Individual differences in pronoun reversal: Evidence from two longitudinal case studies*." Journal of child language 39.1, 2012: 162.

Gil, David, \& Tadmor, Uri. The MPI-EVA Jakarta Child Language Database. A joint project of the Department of Linguistics, Max Planck Institute for Evolutionary Anthropology and the Center for Language and Culture Studies, Atma Jaya Catholic University. 2007.

Girouard, Pascale C., Marcelle Ricard, and Thérèse Gouin Decarie. "The acquisition of personal pronouns in French-speaking and English-speaking children." Journal of Child Language 24.2, 1997: 311-326.

De Heer, Gerrit Koenraad. "Indonesian syntax." Dissertation abstracts international. A. The humanities and social sciences 36.2, 1975. 
Leonard, Laurence B. Children with specific language impairment. Cambridge, MA: the MIT Press. 2000.

MacWhinney, Brian. The CHILDES Project: Tools for analyzing talk. transcription format and programs. Vol. 1. Routledge. 2000.

Oshima-Takane, Yuriko, Yoshio. Takane, and THOMAS R. Shultz. "The learning of first and second person pronouns in English: network models and analysis." Journal of Child Language 26.3, 1999: 545-575.

Ricard, Marcelle, Pascale C. Girouard, and Therese Gouin Decarie. "Personal pronouns and perspective taking in toddlers." Journal of Child Language 26.03, 1999: 681697.

Sneddon, James N. Indonesian: A comprehensive grammar. London: Routledge. 1996 